\title{
MÕNDA BALTISAKSA ELULUGUDEST JA MIS SEAL SEES LEIDA VÕIB
}

\author{
REET BENDER
}

$\mathrm{E}$ lulookirjutusi ja mälestusi uurimisobjektide ning allikatena ei vaidlusta tänapäeval ilmselt enam keegi, vaadeldagu neid pealegi teatud laadi ilukirjandusena. Viimastel kümnenditel Eestit tabanud omaelulookirjutuse buumi on nimetatud ka „mälukirjanduse üleujutuseks” (Hinrikus 2010: 20). Eestikeelne mälukirjandus on, nii nagu eesti ilukirjanduski, suhteliselt hiline ja kuni sõjajärgse ajani ka kaunis väikesearvuline. Ent Eesti mälukirjandus tervikuna, koos baltisaksa omaelulooliste tekstidega, on seevastu oluliselt tihedam ja arvukam. Üldpilti silmas pidades on täiesti õigustatud tõdemus, et „eesti kirjanduse - laiemas mõttes - ja samuti autobiograafilise kirjutuse algust otsides ei saa lähtuda üksnes keelest ja rahvusest, vaid peame lähtuma ka kultuuriruumist" (Hinrikus 2010: 25).

Käesolev artikkel annab ülevaate baltisaksa elulugude uurimisseisust ja allikatest ning vaatleb näidete varal baltisaksa elulugusid kui üht kollektiivsest ajaloomälust ära lõigatud ja unustatud osa Eesti (ja vaikimisi ka Läti) kultuurist, millel on ometi oluline roll kultuuriloolise tervikpildi kokkupanekul. Ainest vaadeldakse kolme alateema kaupa. Esmalt käsitletakse baltisaksa tekstipärandi hulka ja ajalises vaates seda, kuidas, miks ja mis alustel on tegeletud baltisaksa tekstide, sh mälestuste kogumise ja publitseerimisega. Seejärel vaadeldakse baltisaksa tekstide, sh mälestuste tõlkeid eesti keelde $^{1}$ ning baltisaksa elulugude uurimisseisu. Kolmanda teemana jõutakse elulugude endani, tutvustades seda, mida neist leida võib ja nende käsitlemise võimalusi.

Baltikumi mõistetakse käesolevas artiklis selle ajaloolises ulatuses, kolme omaaegse Balti provintsi Eesti-, Liivi- ja Kuramaa piires. Siinses kirjutises kasutatakse termineid autobiograafia, elulugu, mälestused ja memuaarid sünonüümsetena. Teoreetilise tausta moodustab viimasel veerandsajal aastal Balti kirjanduse uurimises edukalt rakendatud ühise kultuurivälja printsiip, mis tugineb Pierre Bourdieu kultuurivälja teooriale ja mida rakendades on baltisaksa kirjandusvälja kirjeldatud saksa kirjandusvälja alaväljana, „mis kujunes integreerituse ja autonoomia pingeväljas”, emantsipeerudes seejärel (vrd Lukas 2006: 40-42). Klaassein, rahvuslik traataed ja valged laigud sobivad iseloomustama siinse mitmekesise ja läbipõimunud kultuurivälja ühest osast mitteteadmise ja -teadlik olemise väljakujunemist. Siinpool Siegfried von Vegesacki „Balti tragöödias” kujutatud ühtaegu nii seisuslikku, sotsiaalset, etnilist, rahvuslikku kui ka keelelist klaasseina (sks die gläserne Wand) on Balti kultuurilise välja kirjusus, teisel pool olev on ajapikku maha vaikitud, unustatud ja lõpuks tundmatuks muutunud. Hoolimata üleskutsetest ja katsetest vaadata üle „rahvusliku” traataia (Annist 1938), on ühisele kultuuri-

${ }^{1}$ Baltisaksa memuaristika uurimist ja tõlkelugu Lätis siin ei käsitleta, kuid artiklis kõneks tulevad tekstid käivad loomulikult terve ajaloolise Baltikumi kohta. 
väljale aja jooksul ja erinevate ideoloogiate toel tekkinud valged laigud, nõnda et lõpuks ei teatagi enam, et midagi on maha vaikitud või üldse eksisteerinud. Ent kirjanduslugugi mõjub ainult eestlastele resp. lätlastele keskendudes „hüppelise ja eimillestki-tekkivana” ning kirjutusfaktid „üksitiste, katkeliste ja kistutena" (Undusk 2011: 564).

Klaasise metafoori on ühise kultuurivälja sümboliks valinud ka Tõnu Õnnepalu (2016), kirjutades klaasveranda rahvusüleseks mälupaigaks. Ühtse terviku moodustanud osised - mõisakultuur ja vana talupojakultuur - on tänaseks kadunud; üks pool, baltisaksa kultuur, aga mälust välja lõigatud, kuigi selle „fantoomvalud ikka vahetevahel tunda annavad” (Plath 2017: 171). Maareformi 100 aasta juubeli künnisel on ehk tekkinud juba piisav distants vaatamaks olnule tagasi sine ira et studio, nagu viitab ka Aadu Must baltlasi Esimeses maailmasõjas vaatleva monograafia eestikeelse versiooni lõppsõnas (Must 2016: 186).

\section{Arvudest ja allikatest}

Siinsete sakslaste koguarv ei ulatunud kunagi üle 180000 (Schlau 1995: 177178). 1934. aasta rahvaloenduse andmetel oli sel ajal veel Eestis elavate ja end sakslaseks pidavate isikute arv napilt üle 16 000, moodustades koos Läti sakslastega ca 65000 isikut koondava rahvusgrupi. Seevastu nende kirjanduslik tegevus oli kirjandusleksikone või andmebaase vaadeldes ebaproportsionaalselt ulatuslik (Redlich 1989; Gottzmann, Hörner 2007; Lukas 2006; EEVA). Kuna Saksamaaga võrreldes olid naised Baltikumis haritumad, elu odavam, teenijaid ja seetõttu ka vaba aega rohkem, oli kaunis suur ka kirjandust harrastavate naiste osakaal, seda enam, et kirjandus polnud nagunii n-ö päris mehetöö (vt Undusk 1993).

Ühe osa baltisaksa tekstidest moodustavad mälestused. Kirjanduslikult liialdades võib väita, et peaaegu kõik baltisakslased on pannud kirja oma mälestused - või siis vähemalt need, kes õppisid Tartu ülikoolis, millel oli keskne roll baltisakslaste haridus- ja elukäigus. Sergei Issakov on hinnanud Tartu ülikooli käsitlevate memuaarteoste hulka tohutuks, saksa keeles on trükki jõudnud neist ca 150 (Issakov 1986: 5). 55 baltisakslase korporatsioonimälestusi XIX sajandi algusest kuni Esimese maailmasõjani koondab neljaköiteline kogumik „Student in Dorpat (und Riga)” (Bertrams 2004-2005), mille allikateks on eraldi ilmunud memuaarteosed, korporatsioonide väljaanded ning käsikirjalised tekstid. Korporatsioonid ise tegelesid vilistlaste mälestuste kogumisega põhiliselt seoses oma ajaloo ja liikmealbumite koostamise ning juubelitega. ${ }^{2}$ Need albumid on väga head laiema isikuloo allikad, kuna sinna lisati ka andmed liikmete perekondliku ringi ja seoste kohta. Kaunis arvukas on ka naiste elulooliste materjalide hulk: nii on Anja Wilhelmi monograafias (2008) baltisaksa ülemkihi naiste elust aastatel 1800-1939 kasutanud pea 180 naise ülestähendusi, millest sadakond on trükis avaldatud, ülejäänud peamiselt pärit Carl-Schirren-Gesellschafti autobiograafiate kogust.

Baltisaksa mälestusi on aja jooksul ilmunud nii eraldi teostena, kogumikes kui ka perioodikas, näiteks kuukirjas Baltische Monatsschrift. XX sajandi algul

${ }^{2}$ Nii näiteks avaldati Friedrich Reinhold Kreutzwaldi tagasivaade oma üliõpilasajale esmalt aastal 1901 korporatsioon Estonia albumi ühes lisas (Kreutzwald 1901), kordustrükina aga korporatsiooni 150 aasta juubeli puhul (Kreutzwald 1971). 
hakati neid materjale kokku koondama ja uuesti välja andma. Üheks produktiivsemaks memuaristika kogujaks ja väljaandjaks oli baltisaksa ajaloolane Friedrich Bienemann jun. (1860-1915). Mälestustekogumiku „Altlivländische Erinnerungen" (1911, järg 1913) väljaandmist põhjendas ta ühelt poolt vajadusega tutvustada möödunud aegu nooremale põlvkonnale, kel pole endal aega laialipillutatud üksiktekstide tagaajamiseks, teisalt aga sooviga eelnenud generatsioonide tundmaõppimise kaudu iseennast mõista, pealegi pakkuvat need „kokku kogutuna avarat ja kütkestavat pilti elu- ja mõtteviisist vanal Liivimaal 19. sajandi esimesel poolel" (Bienemann 1911: III-IV). Memuaarset materjali sisaldab ka kogumik „1812. Baltische Erinnerungsblätter”: eraldi alapeatükis kajastatakse mälestuste, kirjade ja päevaraamatute põhjal Riia eeslinnade mahapõletamist (Bienemann 1912: 106-185). Bienemanni laadi jätkates andis endine Tallinna toomkooli direktor Alexander Eggers (18641937) Saksamaal välja baltisaksa mälestuste kogumiku (Eggers 1926), mille allikmaterjalid pärinesid ajakirjandusest, aga ka korporatsioon Estonia arhiivist.

Esimese maailmasõja eel tekkinud missioonitundlikkus nn baltisaksa asja ajamisel muutus kahe ilmasõja vahel eksistentsiaalselt oluliseks. Huvipakkuv on omaaegne elulugude aktsioon aastast 1931, mil ajalehe Rigasche Rundschau tellimusel ilmusid 16 Saksamaal elava baltisaksa kirjaniku meenutused. Toimetaja põhjendas seeriat vajadusega tutvustada Saksamaal elavaid Balti kirjanikke Balti lugejale ja tõsta neis nõnda ka „muidu kahjuks puudulikku huvi moodsa saksa kirjanduse vastu". Hoolimata pikemast kodumaalt eemalviibimisest oli ikkagi tegu Balti autoritega, sest „tüüpiliselt baltilik olemus, tüüpiliselt baltilik olemine väljenduvad mingil moel kõigis inimestes, kes meie maailmanurgast pärit on. Ja selle tulemuseks on, et kõigi nende kunstnike teostes on siiski olemas midagi sellest balti sfäärist, kuigi seda pole mitte tihti võimalik otseselt tõendada" (Deutsche Dichter... 18. IX 1931).

Uuele tasemele jõudis baltisaksa memuaristika avaldamine Teise maailmasõja järel, mil senine maailm oli lõplikult kokku kukkunud. Kasvas eluloolise materjali kirjapanemise ja avaldamise maht eesmärgiga olnut, toimunut ja üleelatut jäädvustada nii perekonnale kui ka laiemalt järeltulevatele põlvedele, mõnikord on tegu ka enne Teist maailmasõda kirjapanduga. Tihti avaldasid neid tekste järeltulijad. Vahel tehti seda omal initsiatiivil, vahel teiste nõuandel, kui materjal pakkus laiemalt huvi. Nii näiteks avaldasid paruness Angelika (Gella) von Korffi (abielus Dragendorff, 1895-1982) lapsed 1991. aastal oma ema päeviku enamlaste terrori aegsest Riiast aastal 1919: „Sõbrad ja ajaloolased on meil ikka ja jälle palunud see - omal moel ainulaadne - ajastudokument avaldada. Pärast pikka kõhklemist tahame sellele soovile vastu tulla. [---] Meie ema saatus ei olnud tol ajal kindlasti erandlik. Ema leidis aga jõudu (või tröösti?) igapäevaselt üleelatu samal ajal ka kirja panna. Ta ei teadnud, mis võis juhtuda järgmisel päeval või järgmisel tunnil.” (Korff 1991) Korffi päevik avaldati Hirschheydti baltisaksa kirjastuses, ent tihti oli tegu ka omakirjastuslike ja pigem perekondlikuks tarbeks mõeldud väljaannetega, nagu näiteks Hagudis kasvanud Leonhard von Krusenstjerni (1873-1956) 1948. aastal kirja pandud mälestused (Krusenstjern 1979).

Iseloomulikuks jooneks on n-ö pedagoogiline moment: kohalike nähtuste, esemete ja keelendite seletamine, pidades silmas mittebalti lugejaskonda, sh järeltulijaid, kes pole enam Baltikumis sündinud ega kasvanud. Sõltuvalt väljaandjast on vahel lisatud kohanimede konkordants ja kommentaarid. 
Kohati seletavad võõraid väljendeid ja nähtusi lugejale autorid ise, ent mõne autori jaoks on need seletamiseks - ehkki lugejale oleks seda vaja - liiga loomulikud. Keeleliste eripärade ja toidukultuuri tutvustamise heaks näiteks on ajakirjanik Erik G. Vergi (1919-2005) (1995: 64-76, e k 2012) ja põlisest pastorite suguvõsast pärit Ingeborg Kentmanni (1916-1989) (1978: 65-70) mälestused. Nad kirjeldavad ja kommenteerivad eraldi peatükkides koduseid ja kohalikule köögile omaseid roogasid ning tähtpäevi, Kentmann ka Tallinna turu võlusid.

Sellise n-ö baltisaksa kultuuri kursuse juurde kuulub ka baltisaksa sõnavara ning eesti-, läti- või venekeelsete tekstikatkete kasutamine, vahel lahti seletatuna, vahel lihtsalt tsitaatsõnana autori isikliku leksika loomuliku osana. Näiteks kasutab Leonhard von Krusenstjern aidamees Mihklit ja temaga mängitud kiigutamismängu (tekstis eestikeelsena Kiigu-Paua) kirjeldades vaheldumisi nii baltisaksakeelset sõna Kletenkerl kui ka eestikeelset sõna Aidamees, seletades lugejale ainult neist esimest; vennastekoguduse liiget Mihklit kirjeldades seletab ta ühtlasi lahti kohaliku nähtuse Brüdergemeinde (Krusenstjern 1979: 19-20).

Organiseeritult tegeleti mälestuste kogumise ja avaldamisega Saksamaal baltisaksa ühendustes. Hulgaliselt memuaarset materjali leidub Lüneburgis asuvas baltisaksa kultuurikeskuses Carl-Schirren-Gesellschaft, mille aastaraamatus „Jahrbuch des baltischen Deutschtums” on mälestusi avaldatud, sh teemanumbreina, alates 1950. aastatest. Memuaaridele on pühendatud sari „Schriftenreihe der Carl-Schirren-Gesellschaft”. Väiksemaid palu on varasemal ajal ilmunud ka baltisaksa ajalehes Baltische Briefe. Palju mitmekesist, erinevate asutuste, perekondade ja üksikisikute materjali leidub Marburgis asuvas 1950. aastal asutatud Ida-Kesk-Euroopa uurimiskeskuse Herderi Instituudi arhiivis, kus asub suurim Baltica kogu väljaspool Balti riike (arhiivi kogumahust enam kui $80 \%$, Goeze, Wörster 2016).

Balti kirjavara väljaandmisel ja vahendamisel on teenekas 1950. aastal Lääne-Saksamaal asutatud Harro von Hirschheydti kirjastus ja antikvariaat, mis tegeles Baltica, sh memuaristika kirjastamisega. Lisaks raamatutele avaldati memuaarset materjali aastatel 1954-1977 ilmunud kvartalikirjas Baltische Hefte ja sarjas „Die Baltische Bücherei” (1959-1964), kus muust memuaarsest materjalist eristuvad kaks köidet baltisaksa kummituspärimusega (Koskull 1962, 1964). 1970. aastal alustati eraldi memuaristikasarjaga „Baltische Erinnerungen und Biographien”.

\section{Tõlgetest eesti keelde}

Tõlkimisel, sh mälestuste tõlkimisel võib tänasel päeval lisaks aja- ja kultuuriloolises kontekstis orienteerumise keerukustele osutuda komistuskiviks spetsiifiliste baltisaksa väljendite rohkus, mida „tavalistes” sõnaraamatutes ei leidu. Baltisaksa tekstide tõlkeloos on aja jooksul toimunud teatavad nihked selles, mida tõlgitakse. Eelmisel sajandivahetusel kestis tõlgete toel edasi ühine kultuuriväli, tõlgiti palju moes olevaid baltisaksa autoreid, nagu näiteks Panteniuse ajaloolisi romaane (vt Lukas 2006: 593-599). Tõlkimist motiveeris ka eestikeelsete algupärandite nappus.

Eesti Vabariigis orientatsioon muutus, siiski jälgiti baltisaksa kirjanduses toimuvat. Nii avaldati 1935. aastal Postimehes läbi mitme numbri kommen- 
teeritud osaline tõlge Siegfried von Vegesacki romaanitriloogiast „Balti tragöödia”, küll jättis kommenteerija igaks juhuks oma nime panemata (Mida mõtles...). Siiski oli värskete haritlaste suhtumine baltisaksa kirjanduse „pitsiheegelduslikkusesse” (Tuglas 2008: 338-339) pigem eitav. Sealjuures jäi aga märkamata selle hoopis erinev eesmärgistatus, suunatus pigem tegudele kui tekstidele (Undusk 1993) ja enda mõistmine saksa kirjanduse osana, mistõttu selliseid ,juba veidi hapuks läinud hinnanguid baltisaksa kirjanduse kesise kvaliteedi kohta” võib tagantjärele tõlgendada pigem võimetusena „tajuda ühe rahvakillu hingelist omapära" (Undusk 1993: 28). 1930. aastatel oldi eesti kultuuri väärtuses siiski piisavalt veendunud, et vähemalt kultuuriloolise käsitluse juures mõisteti laiema vaatenurga vajadust: „Miks peaksime end vabatahtlikult „rahvusliku” traataiaga eraldama nende kaugete aegade pärandusväärtustest, ainult selle pärast, et nende autorid polnud „verelt”, keelelt ega meelelt eestlased?" (Annist 1938: 988) Samal aastal väljendas sarnast seisukohta teiselt poolt baltisaksa publitsist Kurt Moritz, analüüsides ja võrreldes varasemat ja oma kaasaegset eesti kirjandust baltisakslaste kujutamise vaatenurgast (Moritz 1938: 93).

Teise maailmasõja järgset baltisaksa tekstide tõlkelugu võib iseloomustada kahe asjaolu kaudu: ühelt poolt dissidentluseks kvalifitseeruv üle traataia vaatamine, mille arengule Nõukogude okupatsioon omalt poolt tublisti kaasa aitas, lastes ajaloolisel „saksavihal” asenduda „venevihaga”. Teisalt tõusis just nüüd ja edaspidi esile tekstide teoline pool ehk erinevalt varasemast tõlgiti peamiselt mitteilukirjanduslikke tekste. Nõukogude ajal ilmus Eestis 31 baltisaksa teksti tõlget (neistki pooled ühtede kaante vahel; lisaks veel üheksa Välis-Eestis ilmunut), neist ainult üks ilukirjanduslik.

Laulvast revolutsioonist alates baltisaksa tõlgete vallas toimunut võiks aga nimetada tõlkeplahvatuseks. 1989. aastast kuni 2016. aasta kevadeni on kokku avaldatud pea 300 teksti eraldi väljaannetes, kogumikes või ajakirjanduses (sh kordustõlked ja -trükid ning ka audioraamatud). Umbes viiendik tekstidest on ilukirjanduslikud, ülejäänud kuuluvad ajaloo ja memuaristika valdkonda; memuaarteoste tõlkeid on neljandiku jagu (vrd Bender 2016). Mitteilukirjanduse suurt osakaalu selgitab ka valgete laikude perioodile järgnenud intensiivse mälutöö ja rahvusliku traataia ületamise faas. Oluline on tõlgete puhul kommentaaride ning ees- ja järelsõnade olemasolu: eesmärgiks pole meelelahutus, vaid lugeja informeerimine. Uuem täiendus tõlgetele on eestimaalaste mälestusi koondav kogumik (Wistinghausen 2016). Eraldi valdkonna moodustavad baltisaksa kunstnikud, kelle uurimisega tegeldi juba nõukogude ajal, nüüd on aga lisandunud kunstnike biograafiad ja päevaraamatud (näiteks Leopold von Pezold, Julie Wilhelmine Hagen-Schwarz, August Matthias Hagen ja Carl Timoleon von Neff). Lätis pole teadaolevatel andmetel olukord sugugi nii roosiline: kirjandusteadlane Heinrich Bosse mõne aasta tagustel andmetel oli aastatel 1995-2013 tõlgitud memuaarteoseid kümne ringis (vt Garleff, Bender 2014: 479).

Iseloomulik on baltisaksa tekstide ja memuaarse materjali väljaandmine sarjade koosseisus. Üsna rohkelt on neid ilmunud Loomingu Raamatukogus (vrd Bender 2016). ${ }^{3}$ 2001. aastal alustas kirjastus Huma sarja „Liivimaa klassika”, mis ei jõudnud küll kaugemale neljast köitest (neist üks memuaarne).

${ }^{3}$ Omalaadse kurioosumi moodustavad Monika Hunniuse „Minu onu Hermanni” kaks konkureerivat tõlget, mis mõlemad ilmusid aastal 2000: üks Loomingu Raamatukogu väljaandena ja teine kirjastuselt Kupar. 
Baltisaksa autorid on memuaarse ainesega esindatud kirjastuse Ilmamaa sarjades „Ajajõe tagant” ja „Eesti mõttelugu”. Samast põhimõttest lähtuti ka Akadeemia ja Eesti Päevalehe raamatusarjas „Eesti mälu”, kus avaldati kahe Eestimaa rüütelkonna juhtfiguuri, Eduard von Dellingshauseni ja Eduard von Stackelbergi mälestused. Stackelbergi puhul on eriline, et eesti keeles on sellega olemas tema mälestuste täisväljaanne, kuna saksa keeles on neist avaldatud ainult osa.

\section{Elulood ja mälupaigad}

Baltisaksa memuaristika on viimasel ajal pälvinud tähelepanu ka uurimisobjektina. Baltisaksa memuaaride valguses on kirjutatud Riia (Schenk 2010) ja Tartu linnast (Bender 2014); aga ka kolmest kohalikust keelest (Bender 2017), Umsiedlung'ist (Saagpakk 2007; Bosse 2010), Esimesest maailmasõjast (Saagpakk 2006), vaadeldud baltisaksa kirjanike enesepilte (Garleff 2010) jne. Biograafilist andmestikku sisaldab käsitlus baltisaksa (juhu)luuletajannadest (Kaur 2013). Anja Wilhelmi (2008) on uurinud baltisaksa naiste mälestusi eluperioodide kaupa, käsitledes lapsepõlve, kooliaega, leeri, aega kuni abiellumiseni (sh töötamine ja kontaktid meessooga), abiellumist, emadust. Alternatiivi abielule käsitleb peatükk üksikutest naistest. Wilhelmi on lisanud kõigile teemadele ajaloolise konteksti ja tausta. Käsitletud autoritele on omane baltisaksa kogukonna eripärade iseloomustamine ja ajalooteadlikkus, samuti kollektiivse kogemuse rõhutamine. Huvitava ühisjoonena on esil loodus ja loodusarmastus, mis korreleerub muude Balti loodusmõtte ja keskkonnafilosoofia uurimise tulemustega (vrd Lukas jt 2011). Kuna käsitletud autobiograafiatest suur osa on kirjutatud XX sajandil, moodustas paljude mälestuste olulise kollektiivse mälupaiga kodumaa (sks Heimat), millest sai „turvalise ja endasse pööratud eluruumi kompensatoorne paik”, seotuna koduigatsuse (sks Heimweh) ja kodutusega (sks Heimatlosigkeit), mis omakorda viis ajalookontseptsiooni muutuseni (Wilhelmi 2008: 333) ning lepituseni eestlaste ja lätlastega ehk siis taas rahvusliku traataia ületamiseni, sel korral teiselt poolt vaadates.

Kui asuda lähemalt vaatlema baltisaksa elulugusid, tõusetub kohe küsimus kuidas?, sest aines on väga mahukas ning mitmetahuline, muutes lihtsustatud hinnangutest hoiduva käsitluse ka kriitilise massi tekstide läbitöötamise järel keerukaks.

Levinuim võimalus on lähtuda mingist kindlast aspektist või pöördelisest sündmusest, nagu seda on tehtud, uurides Umsiedlung'it või tudengimälestusi (Bender 2014). Teine võimalus on läheneda asjale kronoloogiliselt, mis eeldab üldistuste tegemiseks suure hulga tekstide läbitöötamist, nagu on seda teinud Wilhelmi. Kolmanda lähtealuse, mida vähemalt osaliselt üritatakse siinkohal rakendada, pakub välja Riiast pärit arhitekti Otto Pirangi (1895-1982) poolt 1947. aastal joonistatud kaardimäng „Heimatquartett” (CSG. Sp2602/89 DII). See kujutab endast kontsentreeritud teravmeelset valikut baltisaksa mälupaikadest: sellest maailmast, kaotatud kodumaast, „mis oli kolmes tähenduses - ruumi, aja ja inimeste poolest kaugele möödanikku jäänud” (Osteneck 2007). Pirangi eeskujuks oli 1925. aastal Riias valminud Balti provintside ehitisi tutvustav mäng „Baltisches Quartettspiel”, mille eesmärgiks oli kokku 
saada neli ühte kategooriasse kuuluvat kaarti. Pirang joonistas mängu esmalt tuttava lastele, tehes sellest käsitsi ja napilt koloreeritud trükiversiooni, mille 600-eksemplarine tiraaž aastail 1951-1952 baltisaksa nädalalehes Baltische Briefe ilmunud kuulutuse peale kiirelt läbi müüdi. Erinevuseks 1925. aasta mängust on aga Pirangi väga avaravaateline lähenemine mõistele baltisch. Tulemuseks on suurt üldistusjõudu omav memuaarartefakt, mis võtab kokku baltisaksa memuaristikas kirjeldatava maailma, mille ühe mälupaiga moodustab ka keel.

Nelja kaupa kokku kogutavaid kategooriaid on selles mängus viisteist: vapid, Riia tornid, Tallinna tornid, jõed, Riia tunnusmärgid, lossivaremed, saatusepöörded, Landeswehr'i väejuhid, tänavakaupmehed, rahvalikud kujud, rahvalikud kombed, napsid, toidud, praktilised esemed, pisiehitised.

Vaatleme mõningaid põhijooni, mida Pirang on oma joonistustega edasi andnud. Nimetatud kategooriad on jaotatavad suureks ja väikeseks ajalooks. Suurt ajalugu esindavad vapid, tornid, ehitised, jõed jm ehk n-ö ametlik osa. Eelkõige aga just pisiehitised (der Prahm 'praam', die Pirte 'saun', die Badebude 'supelmaja', die Heukuje 'heinakuhi'), praktilised esemed (die Liniendroschke 'pikkvanker', der Trumm 'trummel', die Pasteln 'pastlad' ja der Samowar 'samovar'), söögid-joogid, rahvalikud kujud (Ogorodnik, Maroschnik ehk jäätisemüüja, kardavoi ja barankamüüja) esindavad argi- ja keeleajaloolist uurimismaterjali, millel on suur kultuurilooline tähendus. Korrespondeerivas ja täiendavas efektis peitub baltisaksa memuaristika võlu. Baltisaksa mälestused, mis kohati näivadki koosnevat mälupaikadest, annavad asjale teisese vaate, täiendavad ja mitmekesistavad muidu ehk liialt üheülbaliseks kippuvat pilti, avades teatud perioodide ja sündmuste puhul tahke, mida eestlaste kirjutatud memuaarne materjal ei puuduta. Ühtlasi annavad need märku oluliselt suuremast läbipõimitusest siinsel kultuuriväljal, kui seda ehk vahel endale tunnistada tahetakse või ka osatakse. Baltisaksa memuaristikast võib leida üllatavaid paarikuid sarnastele elementidele eesti traditsioonis, mis võiks tegelikult viia ka mõningate seniste seisukohtade ümberhindamiseni.

Nii näiteks annab mõtteainest mardisanditamise kombe tagamaade üle Miitavi raesekretär Julius Eckardt sen . (1810-1885), meenutades oma tudengipõlve Tartut (1829-1833) ja sealseid maskeraadikombeid:

Mardi- ja kadripäeval tavatsesid Tartus ka kõige vaesemad tegelased ennast maskeerida, polnud aga sugugi harv juhus, kui auväärsed mehed, kel turjal viiskümmend ja enam eluaastat, endale paari punaseid laiu pükse jalga tõmbasid, kirju räti turbaniks pähe sidusid ja säärases rõivastuses „türklastena” mööda sõpru ja naabreid käisid. (Eckardt 1911: 179)

Samalaadset kombestikku meenutab baltisaksa naiskirjanik Theophile von Bodisco (1873-1944) oma lapsepõlveaegsest Tallinnast:

Mardipäeva ajal käisid maskid majast majja, enamasti oli loomulikult tegu vaid lähemalt tuttavate inimestega. [---] Pakuti õlut, veini ja üht-teist suupärast. Alles pärast mitut lõbusat tantsu võeti maskid eest, kuigi tegelikult oli ammu enne jõutud ära arvata, kellega tegu on. Mehed ja poisid riietusid näiteks naisteks või nõidadeks, aga ka ammedeks, kanti ka kuradi- või Kasperlimaski. (Bodisco 1997: 30) 
Kui Eesti rahvakalendri andmebaas Berta mainib, et üliõpilasseltsis Veljesto oli tavaks mardikarnevali pidada, siis näib see justkui eimillestki tekkinud olevat. Rääkimata sellest, et Veljestos oli kombeks esitada ka päevakajalisi mardioopereid: traditsiooni alguses seisid jantlikud, kuid põhjalikult ettevalmistatud muusika ja tantsuga päevakajalised rebasteatrid baltisaksa korporatsioonides. ${ }^{4}$

Tihti on taoliste väikeste, kuid üldistusjõuliste detailide leidmine pigem juhuslik ja seosed erinevate tekstide ning autorite vahel sõlmuvad lektüüri mahu kasvades. Peale eesti tekstidele lisavaate avamise suhestuvad baltisaksa tekstid ka omavahel: isikute ring oli siiski suhteliselt piiratud, kirjutasid aga paljud, võimaldades ühtesid ja samu sündmusi või olukordi vaadelda erinevate isikute silme läbi. Teatud määral sarnaneb baltisaksa memuaristika lugemine õnneõngitsemisega: kunagi ei tea, mille otsa sattuda õnnestub, ja leida võib enam-vähem kõike. Teatud eelinfo annavad loomulikult autori nimi, eluaastad, seisus, amet jm, ent palju on oma tarbeks kirjutatud tekste, mille autor ei ole laialt tuntud ühiskonnategelane, nagu näiteks raamatukoguhoidjana töötanud Ingeborg Kentmann. Tema memuaaridest leiab palju argielulisi detaile, näiteks kuidas lahendati majade soojustamise eelsel ajal külma põranda probleem: „Talvel avastasime oma korteri varjuküljed: sel puudus kelder ja nii oli põrand väga külm. Saime jalgadele külmamuhud, mis öösiti voodis hirmsasti sügelesid. Kütmisest polnud siin üldse abi. Istudes torkasime kõige parema meelega jalad vateeritud jalakotti." (Kentmann 1978: 110)

\section{Läbipõimunud suur ja väike ajalugu 1918-1921}

Kui vaadelda aga suurt ajalugu ja suuri sündmusi, siis ka nende juures võib leida väikeseid detaile, mis heidavad valgust hoopis teistele aspektidele. Nii kirjeldab Liivimaalt pärit Herbert von Blanckenhagen (1892-1985) oma mälestustes muuhulgas väeteenistust Landeswehr'is ja Riia vabastamist enamlaste käest, põigates korraks ka toidukultuuri valdkonda. Nimelt kirjeldab ta Landeswehr'i rahvusroa, ilmselt enamikule eestlastest tuttava koogelmoogeli valmistamist:

Koogelmoogeli kloppimise heli kuulus lihtsalt Landeswehr'i üksuste juurde. Mune löödi vahtu õhtul, hommikul, pärast tallitööd, lõuna ajal, rongi peal, varustust peale ja maha laadides, marsipausil ja ka lahingus. See muutus omamoodi maaniaks. Väga toitvaks maaniaks igatahes. Ma pole elus kunagi rohkem kaalunud kui tookord. Mune oli ju igal pool saada ja suhkrut jaotati nagunii. (Blanckenhagen 1966: 253)

Kui eesti ajalookirjutuses tõsteti 1930. aastate teisel poolel pjedestaalile Võnnu lahing ja oluliseks mälupaigaks on ka Paju lahing, siis baltisaksa traditsioonis oli kesksel kohal hoopis Riia vabastamine enamlaste käest Landeswehr'i poolt 22. mail 1919. Pirangi kaartidel pole see mälupaik pöördeliste sündmuste all - need on seotud pigem liikumiste ja ümberpaigutumistega,

4 Rebasteatri ettevalmistust XX sajandi alguses korporatsioonis Livonia on oma tudengimälestustes kirjeldanud kirjanik Siegfried von Vegesack (1888-1974) (1963: 9698), Riia notari poeg, arstiks õppinud Heinrich Bosse (1829-1869) (1897: 52-55) on elavalt meenutanud pool sajandit varasemat mardipäevaaegset etendust korporatsioonis Estonia. 
nagu Aufsegelung, Umsiedlung, Flucht ja Auswanderung (Liivimaa koloniseerimine, ümberasumine, põgenemine ja väljarändamine) -, kuid selle asemel on eraldi kategooria Landeswehr'i väejuhid: Fletcher, Medem, Engelhardt ja Manteuffel. Palju on kirjeldatud nn baltisaksa Kuperjanovi Hans von Manteuffeli (1894-1919) langemist Riia vabastamisel:

Ühes esimese käputäie vabatahtlikega oli ta tormanud üle silla, kohe paar meest kokku võtnud ja ühes nendega tsitadellini tunginud. Kui juba sillapea moodustunud eelvägi oli vaid pisike saareke keset vaenlasi..., siis oli tsitadellini tungimine vapruse tipp ja ühtlasi ka kogu ettevõtmise kroon. (Blanckenhagen 1966: 271)

Riia kindluseni jõudmine oli vajalik baltisaksa tsiviilelanikest vangide vabastamiseks, kelle seas panid enamlased toime samasuguse massimõrva nagu Tartus. Et need sündmused aga eesti vaatenurgast välja jäid, tõdeti ka Vegesacki „Balti tragöödia” arvustuses: „Ja et nimelt saksa kirjanik on võinud tuua Tartu Krediitkassa sündmustikku pea täiuslikult ning et Eesti kirjanikkude eest nagu varjule on jäänud enamlaste hirmuteod, see on iseloomulik ja sümptoomiline ühtlasi." (Mida mõtles... 11. VI 1935)

Tõepoolest, bolševike hirmuvalitsus 1918-1919 moodustab olulise, kuigi hirmuäratava baltisaksa mälupaiga ning tollaseid sündmusi kajastatakse nende tagasivaadetes, kes selle aja Tartus, Riias või ka mujal üle elasid (või sellele distantsilt kaasa elasid). Nii meenutab Tartu ülikooli koguduse pastori Traugott Hahni (1875-1919) arreteerimist ja mõrva tema lesk Anny Hahn, kirjeldades muuhulgas ka luteri ja õigeusu vaimuliku seni võimatuna näinud nn teineteiseleidmist:

Mõni päev enne oma arreteerimist oli Traugott otsinud üles vene piiskopi Platoni, mõlemad mehed, kel seni polnud eri konfessioonide esindajatena olnud mingisuguseid kokkupuuteid, toetasid teineteist vastastikku otsuses oma koguduse juurde jääda. Vestluse lõpus oli piiskop öelnud: „Nüüd me näeme, et konfessioonid on vaid seinad, mida inimesed ehitavad, kõigi meie üle on aga üks ja seesama Jumal ja Õnnistegija.” (Hahn 1969: 83-87)

Hilisem botaanikaprofessor ja ökoloog Heinrich Walter (1898-1989) kirjeldab eesseisvate läbiotsimiste kartuses padrunite ja saabli peitmise aktsiooni Tartus. Padrunid viidi õe muhvi peidetuna Toomemäele ning poetati siis sügavasse lumme, saabel aga visati esmalt aeda lumme, öise sula saabumise järel korjati sealt salaja üles ning lasti mustadesse naistesukkadesse mässituna nööri otsas kahe maja vahelisse tulemüüri prakku, „kus see asub ilmselt veel tänagi, kui just ühte neist kahest majast pole vahepeal maha lammutatud” (Walter 1981: 35-37). Palju leidub sarnaseid kirjeldusi enamlaste 1918. aasta detsembrist kuni 1919. aasta maini kestnud võimuajast Riias, ühes arreteerimiste, pidevate läbiotsimiste, omavoli, hukkamiste, nälja ja kõrge suremusega.

Kohati ei puudu aga ka teatav koomika. Nii sõlmis 1895. aastal Kolga mõisas sündinud ja Riias kasvanud paruness Angelika von Korff fiktiivabielu „mis on nagunii vaid formaalne, sest bolševike perekonnaseisubürool pole nagunii mingisugust legitiimsust” - oma venna sõbra, kodanikuseisusest arsti Alexander Arbusowiga, et pääseda enda kohustuslikust ülesandmisest pärast 
aadli lindpriiks kuulutamist. Teine kandidaat oli välisriigi kodanik Buwig Zalewsky, ent üleöö paberite ajamine konsuli juures võttis aega, mistõttu polnud „pulmapäeva” ennelõunal peigmehe isik veel paigas. Arbusow lubas abielu sõlmimisel igatahes kohal olla: „emma-kummana, kas mehe või tunnistajana, kuid meelsamini mehena!" Konkurent sai paberid korda, kuid preili Korff teatas talle, et „dr. Arbusow võttis juba pärastlõuna vabaks ja ma ei saa teda niimoodi ninapidi vedada”, mispeale konkurent siirdus neid perekonnaseisubüroosse kirja panema (Korff 1991: 128-132). Bolševike dokument tõepoolest ei kehtinud: Arbusow suri 1932. aastal ikka poissmehena (Album Fratrum Rigensium: 422). Seda fiktiivabielu mainib oma mälestustes ka kirjanik Gertrud von den Brincken, kes kirjeldab pikemalt ka Angelika noorema õe Erika vanglaelamusi. Erika oli üks väheseid ellujäänuid Riia keskvanglas, mis asus linnast väljas ja kuhu vabastajad jõudsid hilinemisega: enne olid bolševikud jõudnud vangid kuulipildujatulega mõrvata (Brincken 1977: 114-121).

Angelika noorpõlvesõbranna Camilla von Stackelberg (1894-1978) elas selle aja üle Tartus, oma mälestustes kirjeldab ta hirmuatmosfääri ja tegutsemisstrateegiaid, muuhulgas paberite peitmist nii madratsi kui ka lumekihi alla katusel (Stackelberg 2003: 122). Camilla arstist kihlatu ja esimene abikaasa Ricko von Staden aga laskis ennast „koos mitme teise ohtusattunud härraga paigutada Emajõe taga asuvasse hullumajja. Seal oli juhataja keegi juudist arst, meie suhtes heatahtlik inimene, kes kogu seda rühma varjas ja kaitses." Vangistatuid valvati karmilt ja kokku õnnestus arreteeritutest põgeneda vaid kahel mehel: üks neist ronis aknast välja ja laskus vihmaveetoru mööda alla, et siis jalgsi kuuskümmend kilomeetrit vanaisa mõisani minna, kus ta „kohe tulevahetusse sattus”. Teine aga jalutas lahti ununenud vangikambri uksest lihtsalt välja ja „astus koridore mööda kõigist vahipostidest ja soldatitest niisuguse meelerahuga mööda, et kellelegi ei tulnud mõttessegi teda peatada". (Stackelberg 2003: 123)

Riias elanud baltisaksa leksikograafi ja toonase kooliõpetaja Oskar Masingu (1874-1947) abikaasa Isa Masingu (1881-1967) päevikust võib samuti leida läbiotsimiste kirjeldusi ning asjade peitmisstrateegiaid:

Kell üheksa [õhtul] ilmusid kaks bolševikku, kes Erich Schultzi ${ }^{5}$ küsisid ja pärast lühikest ülekuulamist kõik tema hõbeda ja 300 rubla ära võtsid. Kohe seejärel peitsime oma raha ja hõbeda veel paremini ära, et sellisteks röövretkedeks paremini valmis olla. Väiksemad lusikad peitsin ma üles kroonlühtri peale, nagu ka kuldasjad, suuremad lusikad ja kahvlid panin väljatõmmatava laua alla põikplaadi peale. Kui olime kraamimise lõpetanud, istusime Oskariga mõnusalt kirjutuslaua taha. Kell pool kaksteist kõlas uuesti uksekell. Sisse tormasid neli tüüpi revolvritega ja põrutasid magamistuppa, kus magasid lapsed. [---] Nad sorisid laste kappides, pärani lapsesilmad neid põrnitsemas, tulid seejärel välja ja hakkasid meie kirjutuslaudades tuhnima. Nad katsusid käega ka raamatute tagant, kuhu olin just raha peitnud, kuid kummalisel kombel ei leidnud seda. Siis otsiti veel läbi meie magamistuba, lõpuks veel ka köök ja käsikamber. [---] Olin juhuslikult leiba küpsetanud ja pakkusin seda neile kogu aeg, et neid veidi leebemalt meelestada. Kell kaks ütles üks neist, et Oskar peab kaasa minema. (Masing 14. II 1919)

\footnotetext{
${ }^{5}$ Allüürnik.
} 
Nii nagu paruness Korffi puhul, oli oluline oludega kohanemine: sellest võis sõltuda ellujäämine. Nii päästis Isa Masing altkäemaksu abil vanglast vabaks oma abikaasa, päästes ühes sellega ka baltisaksa keele uurimise. Tema poolvend Eduard ja vennapoeg Arved Sticinsky aga mõrvati, sest sugulased üritasid neid ausate inimestena endisaegsel moel advokaadi abil vabaks päästa. Pärast Riia vabastamist maeti mõrvatud massihauast ümber:

Soojas suveöös rändasime kaheksakümne inimesega Bickerni' ${ }^{6}$ metsa. [---] Enamikku ohvritest oli tulistatud pähe, mis laseb meil loota, et need vaesed hinged surid koheselt. [---] Arved ja Edi lebasid tihedalt kõrvu, ilmselt olid need vaesed teineteisele kuni lõpuni toeks. [---] Päike tõusis aegamööda ja valgustas kurba vaatepilti. Kella kaheksaks hommikul oli kõik möödas ja kirstud viidi edasi erinevatesse surnuaedadesse. [---] Meie perekond on nii kokku kuivanud, kolme kuu jooksul oleme kaotanud kolm meest. (Masing 11. VII, 16. VII 1919)

Baltisaksa isikuloolise ja memuaarse materjali puhul võib sageli leida võrreldavaid allikaid ja samas sündmuses osalenud inimes(t)e refleksioone. Eelkirjeldatud sündmust on meenutanud Isa Masingu sugulane Gertrud Sticinsky (1903-1997) aastatel 1976-1983 perekonnale kirjutatud ja seni avaldamata mälestustes: „Onu Edi ja Arved kaevati kuid hiljem ühishauast välja ja maeti Riia surnuaiale. Tädi Isa, Lori Masingu ema, oli väljakaevamise juures ja tundis nad ära kaelasidemete ja mansetinööpide järgi." (Sticinsky: 22) Nagu näha, on tekst suunatud autori järeltulijatele, kellele esitatakse sugulussidemete kohta täpsustavaid andmeid, viidates Isa Masingu tütrele, kes sündmuste toimumisajal oli väike laps.

Enamlastega kaasnes alati nälg ja puhkes õitsele must turg. Nimekas baltisaksa ajaloolane, Isa Masingu nõbu ja toonane gümnasist Reinhard Wittram (1902-1973) on meenutanud toiduainete hankimist:

Ma ei tea, kuidas kõige paremini kirjeldada nälga. Mäletan kahte momenti, mil see pani omamoodi värisema, tekitas nõrkusetunde ja kalduvuse vägivallale: üks kord oli, kui ema andis sahvris mulle väljaspool söögiaega paar viilu punapeeti, mis ma alla kugistasin; teine kord retkel mitme kilomeetri kaugusele linnast välja, kus ma käisin koos oma nõo Anna Gulekega, et vahetada talumeeste juures kallis lauapesu, mis meil seljakottides kaasas oli, toiduainete vastu. Meil polnud palju õnne ja peamiseks saagiks oli suur ämber hapukapsaid. Tagasiteel oli nälg nii kohutav ja lõikav, et me ämbri, mida kahe vahel tassisime, iga kümne sammu järel tee peale maha panime ja käega suutäie hapukapsast võtsime. (Wittram 2002: 66-67)

Toonast suurt poliitikat ja oma väikest osalust selles meenutab Tartus sündinud advokaat Woldemar Hartmann (1874-1962), kes kirjutas oma mälestuste kõnealuse osa 1943. aastal Poolas, jättes kirjutamise katki enne Umsiedlung'ini jõudmist (vältimaks ebameeldivusi võimudega) ja lõpetades kirjutamise aastail 1946-1947 (Hartmann 2004: 8). Ta pajatab oma missioonist Konstantin Pätsi ülesandel 1918. aasta lõpul, mil ta pidi teejuhi ja tõlgina saatma lahkuvaid Saksa vägesid kuni Läti piirini. Kirjeldusse lipsab aga sisse pisidetail, mis on iseloomulik baltisaksa mälestuste keelelisele küljele:

${ }^{6}$ Mets Riia lähedal, läti k Biķernieku. 
olles Viljandis Saksa vägedele järele jõudnud, peab ta ka univormi selga tõmbama, kiivriga on aga väga külm: „Varsti külmetasid mu pea ja kõrvad nii hirmsasti, et ma räpase teraskiivri soojema karvamütsi (tuisumüts ${ }^{7}$ ) vastu vahetasin." (Hartmann 2004: 121) Pätsi korraldusel asus Hartmann täitma ka teist missiooni: hankima Eesti riigile Lätist Saksa vägedelt relvi ja varustust. Liepajas jõudiski ta kokkuleppele ja võis rõõmustava uudisega Tallinna naasta, koos Landeswehr'i esindajaga Pätsiga kohtudes tegid nad ettepaneku osa Landeswehr'i üksusi viia üle Narva rindele:

Ta palus mul kahe päeva pärast tagasi tulla, selleks ajaks on asja valitsusega arutatud ja otsus langetatud. Lahkudes kohtasin eestoas oma tuttavat Läti mereväeohvitseri kahe silmatorkavalt riietatud keskealise läti härra saatel, kes pärast meid sisse läksid. Nagu ma portjeelt kuulsin, oli tegu Läti diplomaatiliste esindajatega. Nähtavasti oli Päts neile Landeswehr'iga seotud ettepanekust rääkinud ja need olid andnud talle nõu see tagasi lükata, sest kui me kaks päeva hiljem uuesti tulime, ütles Päts meile, et valitsus olevat pärast pikemat arutelu selle ettepaneku siiski tagasi lükanud. Nagu hiljem selgus, olid sel suured ja halvad tagajärjed. (Hartmann 2004: 135-136)

\section{Lõpetuseks}

Nagu näha, leidub baltisaksa mälestustes nende pöördeliste aastate kohta väga erinevat informatsiooni. Ühel poolt täidavad meenutused lünka eesti kultuurimälus, mis puudutavad nende aastate traagilisi sündmusi, lähemale nihkub Riia, kus oli Balti provintside kõige suurem saksa elanikkond. Lisavarjundeid omandab eesti kollektiivses mälus muidu väga ühekülgselt kujutatud Landeswehr. Kirjeldustest ilmnevad ellujäämisstrateegiad: ellu jääb see, kel on õnne ja kes on kohanemisvõimelisem. Ähvardava ohu ees leiavad ühise keele luteri pastor ja vene õigeusu piiskop, mis kõiki varasemate aastakümnete vastuolusid arvestades on äärmiselt märkimisväärne. Lisandub huvitavaid vaateid suure poliitika pinnasondeerimistele, valikuvõimalustele ja -võimatustele. Tuisumüts ja koogelmoogel (sks Tuisomütze ja Goggelmoggel) annavad aimu ühisosast keeles ja toidukultuuris. Baltisaksa mälestusi tasub lugeda ja uurida: kunagi ei või kindel olla, mida leiab, kuid midagi leiab kindlasti.

Lõpetuseks saab Eesti Rahva Muuseumi uue hoone avamise kontekstis aktuaalsel Raadi lossiga seotud teemal sõna Woldemar Hartmann, kes advokaadina esindas maareformi aegu Saksamaale põgenenud baltisakslasi ja hoolitses nende vara, muuhulgas ka Raadi lossis olevate kunstiväärtuse eest, kirjeldades seda oma väga põnevates ja sisukates mälestustes:

Et Liphart Raadi galerii pärast muret tundis, on täiesti mõistetav. 1921. aastal turgatas talle lõpuks pähe õnnelik mõte. Ta kirjutas mulle, et on valmis Eesti riigile või Tartu ülikoolile - kes pidi Raadi hiljem endale õppe-katsejaamaks saama - kinkima mitmeid maale, skulptuure ning raamatuid tingimusel, et ülejäänu, talle jääva osa, tohib ta maalt välja viia. Selle asjaajamisega seoses

${ }^{7}$ See baltisaksa keelepruugis levinud sõna on saksakeelses originaaltekstis eestikeelne. Kasutusel oli ka pooleldi saksakeelne variant Tuisomütze, vahel aga ka Läcki-Läcki, mille kirjaviis võis varieeruda. 
sooritasin oma esimese ja ainsa teadliku võltsimise. Liphart kirjutas mulle, et ta on nõus kinkima 25 originaalmaali ja 10 originaalskulptuuri, neid nimeliselt üles lugedes. Ma lasin kirjutusmasinal kirja kinkimist puudutavast osast teha ärakirja, milles vähendasin kingitavate piltide arvu 10-le ja skulptuuride arvu 5-le. Tegelikult oli mul täievolilise esindajana formaalselt selleks ka õigus, kuid päris puhas mu südametunnistus siiski ei olnud. Pakkumine võeti Eesti valitsuse poolt, mida toona juhtis mulle ka isiklikult tuttav Tartu lehetoimetaja Jaan Tõnisson, rõõmu ja tänuga vastu, ja mul õnnestus - ma polnud selle üle mitte vähe uhke - saada vastutasuks mitte ainult tollivaba väljaveoluba, vaid ka Eesti valitsuse lubadus saata tasuta kohale kogu pakkematerjal ning pakkimine ja transport laevale katta riigi kuludest. (Hartmann 2004: 166-168)

Artikli valmimisel on abiks olnud teadusgrant IUT34-30 „Tõlkeideoloogia ja ideoloogia tõlkimine: kultuuridünaamika mehhanismid Eestis vene ja nõukogude võimu tingimustes 19.-20. sajandil”.

\section{Käsikirjad ja arhiiviallikad}

Masing = Isa [Louise] Masing. Tagebuch. Kladde II. 21. I 1917 - 6. VIII 1920. Käsikiri Gabriele von Mickwitzi valduses.

Sticinsky $=$ Gertrud Sticinsky. Erinnerungen 1976-1983. Käsikiri Gabriele von Mickwitzi valduses.

CSG. Sp2602/89 DII (Archiv der Carl-Schirren-Gesellschaft) - Otto Pirang. Heimatquartett.

\section{Internetiallikad}

Berta - Eesti rahvakalendri tähtpäevade andmebaas. http://www.folklore.ee/ Berta/tahtpaev-mardipaev.php (1. V 2017).

EEVA - Eesti vanema kirjanduse digitaalne tekstikogu https:/utlib.ut.ee/eeva/ index.php?lang=et\&do=index (1. IV 2016).

\section{Kirjandus}

Album Fratrum Rigensium. Fraternitas Rigensis 1823-1979. Bearbeitet von Robert Gross und Heintz Meyer-Eltz. Hrsg. im Auftrage des Philisterverbandes. München, 1981.

Annist, August 1938. Meie valgustusaja kirjandus ja Krahv Manteuffel. (Aiawite peergo walgussel 100. a. juubeli puhul.) - Looming, nr 9, lk 987-1000.

Baltisches Quartettspiel 1925. Mit historischen Notizen von Dr. phil. K[arl] v. Löwis of Menar und Zeichnungen von S[iegfried] Bielenstein. Der baltischen Jugend gewidmet von Dr. Edgar v. Pickardt. Riga: Jonck \& Poliewsky.

Bender, Reet 2014. Tartu baltisaksa tudengimälestustes. Koht ja inimesed. Keel ja Kirjandus, nr 3, lk 203-224.

B ender, Reet 2016. Baltisaksa tekstide tõlgetest eesti keelde alates Teise maailmasõja lõpust kuni tänase päevani. Lisandusi eesti tõlkeloole. Magistritöö tõlke- 
õpetuse erialal. Tartu: Tartu Ülikool. http://dspace.ut.ee/handle/10062/53501 (17. VIII 2017).

B end er, Reet 2017. „Babel” im Baltikum. Die drei Ortssprachen Deutsch, Estnisch und Russisch in deutschbaltischen Lebenserinnerungen. - Zum Beispiel Estland. Das eine Land und die vielen Sprachen. (Valerio 19.) Koost Silke Pasewalck, Anna Bers, R. Bender. Göttingen: Wallstein, lk 50-64.

B ertrams, Kurt U. (koost) 2004-2005. Student in Dorpat. Erinnerungen baltischer Korporierte. 4 Bde. Hilden: WJK-Verlag.

Bienemann, Friedrich (koost) 1911. Altlivländische Erinnerungen. Reval: F. Kluge.

B i e n e m a n n Friedrich (koost) 1912. 1812. Baltische Erinnerungsblätter. Herausgegeben von Dr. Fr. Bienemann. Mit zahlreichen Porträts und Ansichten. Riga: Jonck und Poliewsky.

Bi en e mann, Friedrich (koost) 1913. Aus vergangenen Tagen. Der „Altlivländischen Erinnerungen" Neue Folge. Reval: F. Kluge.

Blancken hagen, Herbert von 1966. Am Rande der Weltgeschichte. Erinnerungen an Alt-Livland 1913-1923. Göttingen: Vandenhoeck \& Ruprecht.

B od is c o, Theophile von 1997. Versunkene Welten. Erinnerungen einer estländischen Dame. Toim Henning von Wistinghausen. Weissenhorn: Konrad.

B o s s e, Heinrich 1897. Skizzen aus Dorpat. Von einem alten Dorpater Studenten. Riga: Schnakenburg. [Esmatrükk anonüümselt 1862.]

B os s e, Jana Elena 2010. Siebzig Jahre nach der Umsiedlung - deutschbaltische Zeitzeugen erinnern sich. - Umgesiedelt - Vertrieben. Deutschbalten und Polen 1939-1945 im Warthegau. (Tagungen zur Ostmitteleuropa-Forschung 29.) Toim Eckhart von Neander, Andrzej Sakson. Marburg: Herder-Institut, lk 30-42.

Brincken, Gertrud von den 1977. Land unter. Erlebnisse aus zwei Weltkriegen, Bolschewikenzeit und Nachkriegsjahren. Darmstadt: Bläschke.

Deutsche Dichter... = Deutsche Dichter baltischer Herkunft über ihr Leben und Werk. - Rigasche Rundschau 18. IX, 19. IX, 26. IX, 3. X, 10. X, 17. X, 24. X, 30. X, 7. XI, 14. XI, 21. XI, 28. XI, 5. XII, 12. XII, 21. XII 1931, 2. I 1932.

Eckardt, Julius 1911. Altrigasche Jugenderinnerungen 1812-1834. - Friedrich Bienemann, Altlivländische Erinnerungen. Reval: F. Kluge, lk 155-190.

Eggers, Alexander (koost) 1926. Baltische Lebenserinnerungen. Gesammelt und herausgegeben von Alexander Eggers. Heilbronn: Eugen Salzer-Verlag.

G a r l e ff, Michael 2010. Selbstäußerungen deutschbaltischer Schriftsteller aus den Jahren 1931-1932. Die Artikelserie „Deutsche Dichter baltischer Herkunft über ihr Leben und Werk” in der Rigaschen Rundschau. - Berichte und Forschungen. Jahrbuch des Bundesinstituts für Ostdeutsche Kultur und Geschichte 17/2009. München: Oldenbourg Verlag, lk 215-269.

Garleff, Michael, Bender, Reet 2014. Baltisaksa kirjanduse retseptsioon XX sajandil. - Keel ja Kirjandus, nr 6, lk 478-481.

Goeze, Dorothee M., Wörster, Peter 2016. Die Dokumentesammlung im Herder-Institut. Geschichte und Profil. Marburg: Herder-Institut.

G ottzm a n n, Carola, Hörn er, Petra 2007. Lexikon der deutschsprachigen Literatur im Baltikum und in St. Petersburg. Vom Mittelalter bis zur Gegenwart (I-III). Berlin-New York: Walter de Gruyter.

Hahn, Anny 1969. Es gibt einen lebendigen Gott. Metzingen: Brunnquell-Verlag der Bibel- und Missionsstiftung.

Hartmann, Woldemar 2004. Erinnerungen 1874-1962. Als Jurist in RussischPolen, in Estland und im Warthegau. Kommentiert und herausgegeben von 
Heinz von zur Mühlen. (Schriftenreihe der Carl-Schirren-Gesellschaft 8.) Lüneburg: Carl-Schirren-Gesellschaft.

Hinrikus, Rutt 2010. Eesti autobiograafilise kirjutuse kujunemisest 18. sajandist Teise maailmasõjani. - Methis. Studia humaniora Estonica, kd 4, nr 5-6, lk 20-37.

Is s akov, Sergei (koost) 1986. Mälestusi Tartu ülikoolist. (17.-19. sajand.) Tallinn: Eesti Raamat.

Ka u r, Kairit 2013. Dichtende Frauen in Est-, Liv- und Kurland 1654-1800. Von den ersten Gelegenheitsgedichten bis zu den ersten Gedichtbänden. (Disserationes litterarum et contemplationis comparativae Universitatis Tartuensis 11.) Tartu: Tartu Ülikooli Kirjastus.

Kentm a n n, Ingeborg 1978. Eine Atempause lang. Kindheit und Jugend im Baltikum zwischen zwei Weltkriegen. Freiburg: Herder.

Korff, Angelika (Gella) von 1991. Riga 1919. Ein Tagebuch. Hannover-Döhren: Harro von Hirschheydt.

Koskull, Josi von (koost) 1962. Spukhäuser im Baltikum. Erlebnisberichte und Mitteilungen. (Die baltische Bücherei 8.) Hannover-Döhren: Harro von Hirschheydt.

Koskull, Josi von (koost) 1964. Spukhäuser im Baltikum. Erlebnisberichte und Mitteilungen 2. Folge. (Die baltische Bücherei 14.) Hannover-Döhren: Harro von Hirschheydt.

Kreutzwald, Friedrich Reinhold 1901. Brief des Dr. med. Friedrich Reinhold Kreutzwald. - Nachträge zum Album Estonorum. Heft 3, 1899/II-1900/II. Jurjew: C. Mattiesen, lk 27-31.

Kreutzwald, Friedrich Reinhold 1971. Brief des Dr. med. Friedrich Reinhold Kreutzwald. - Estonia 1821-1971. Gedenkschrift zu ihrem 150 Stiftungstag. Hrsg. vom Philisterverband. Marburg, lk 24-26.

Kr u s e n stjer n, Leonhard von 1979. Erinnerungen. Aalen: A. von Krusenstjern. Lukas, Liina 2006. Baltisaksa kirjandusväli 1890-1918. (Collegium litterarum 20.) Tartu-Tallinn: Underi ja Tuglase Kirjanduskeskus, Tartu Ülikooli kirjanduse ja rahvaluule osakond.

Luka s, Liina, Plath, Ulrike, Tü ür, Kadri (koost) 2011. Umweltphilosophie und Landschaftsdenken im baltischen Kulturraum. Environmental Philosophy and Landscape Thinking. (Collegium litterarum 24.) Tallinn: Underi ja Tuglase Kirjanduskeskus.

Mida mõtles... = Mida mõtles balti sakslus. Surmatants Liivimaal. - Postimees 1935, 29. V, 30. V, 31. V, 1. VI, 2. VI, 3. VI, 4. VI, 6. VI, 7. VI, 8. VI, 11. VI.

Moritz, Kurt 1938. Der baltische Deutsche in der neuen estnischen Literatur. Baltische Monatshefte. Riga: Ernst Plate, lk 93-98.

Must, Aadu 2016. Muutugu ja kadugu! Baltisakslased ja Esimene maailmasõda. Tartu: Tartu Ülikooli Kirjastus.

Os te ne ck, Dieter 2007. Baltische Quartette. Vortrag beim Treffen der Familienkartenspielesammler 2007 in Marburg. http://www.e-s-g.eu/sammelgebiete/themen/familienkartenspiele/quartettbaltische/ (1.VI 2017).

Plath, Ulrike 2017. Klaasveranda ilma klaasita. Kolm võimalust mõista mõisakultuuri 21. sajandil. - Vikerkaar, nr 1-2, lk 171-175.

Redlich, May 1989. Lexikon deutschbaltischer Literatur. Eine Bibliographie. Köln: Wissenschaft und Politik Berend von Nottbeck.

Sa a pakk, Maris 2006. Der Erste Weltkrieg in den autobiographischen Texten deutschbaltischer Autoren. - Journal of Baltic Studies, nr 37, lk 1-21. 
S a g p akk, Maris 2007. Umsiedlung baltisaksa mälestuskirjanduses. - Tuna, nr 4 , lk 38-51.

Schenk, Klaus 2010. Riga in der deutschbaltischen Erinnerungsliteratur zwischen Fakten und Fiktion. - Erinnerungsmetropole Riga. Deutschsprachige Literatur- und Kulturvielfalt im Vergleich. Toim Michael Jaumann, K. Schenk. Würzburg: Königshausen \& Neumann, lk 189-207.

Schlau, Wilfried 1995. Zur Wanderungs- und Sozialgeschichte der baltischen Deutschen. - Tausend Jahre Nachbarschaft. Die Völker des baltischen Raumes und die Deutschen. Toim W. Schlau. München: Bruckmann, lk 177-185.

St a ckelberg, Camilla von 2003. Tuulde lennanud lehed. Mälestusi vanast Baltikumist. Tlk Vladimir Beekmann. Tallinn: Olion.

Tugla s, Elo 2008. Tartu päevik 1928-1941. Tallinn: Tänapäev.

Undusk, Jaan 1993. Baltisaksa kirjandus: tegu ja tekst. - Vikerkaar, nr 10, lk 23-30.

Un d u s k, Jaan 2011. Baltisaksa kirjakultuuri struktuurist. Ärgituseks erinumbri lugejale. - Keel ja Kirjandus, nr 8-9, lk 561-571.

Veges a ck, Siegfried von 1963. Meine Erinnerungen an die Livonia. - Beiträge zur Erinnerung an die Livonia Dorpati 1822-1962. Hrsg. vom Philisterverein der Livonia. Hamburg: Harry von Hoffmann-Verlag, lk 90-98.

Ver g, Erik G. 1995. Auf der Begeist'rung Schwingen. Erinnerungen an eine Kindheit und Jugend im Baltikum. Husum: Husum Druck- und Verlagsgesellschaft. [Tõlge eesti keelde: Verg, Erik. G 2012. Vaimustuse tiivul. Lapsepõlve- ja noorusmälestused Baltikumist. Tlk Iris Assad. Tallinn: Nornberg \& Co.]

W alt e r, Heinrich 1981. Bekenntnisse eines Ökologen. Erlebtes in acht Jahrzehnten und auf Forschungsreisen in allen Erdteilen. Stuttgart-New York: Gustav Fischer-Verlag.

Wilhelmi, Anja 2008. Lebenswelten von Frauen der deutschen Oberschicht im Baltikum 1800-1939: Eine Untersuchung anhand von Autobiographien. Wiesbaden: Harrassowitz-Verlag.

Wistinghausen, Henning von (koost) 2016. Revali ja Peterburi vahel. Eestimaalaste mälestusi kahest sajandist. Eestimaa rüütelkonna ülesandel koostanud Henning von Wistinghausen. Tallinn: Argo.

Wittram, Reinhold 2002. Angst und Hunger. - Erlebte Geschichte. Deutschbalten im 20. Jahrhundert. Ein Lesebuch. Toim Elgin Berg jt. (Schriftenreihe der Carl-Schirren-Gesellschaft 7.) Lüneburg: Carl-Schirren-Gesellschaft, lk $65-67$.

Õnne palu, Tõnu 2016. Klaasveranda. Tallinn: Varrak.

\section{Baltic-German autobiographies as a valuable source material}

Keywords: Baltic Germans, translation history, memoirs, memory places

The article addresses Baltic-German autobiographical texts as an organic part of Estonian cultural history and memory literature, which is, however, a severed and forgotten part of the collective historical memory. First, the article introduces the volume of the survived Baltic-German textual heritage, and analyses, in a historical perspective, how, why and on what grounds Baltic-German autobiographies have been collected and published. Secondly, the article examines the available Estonian translations of and the present state of research into Baltic-German auto- 
biographies. Thirdly, some concrete biographies are used to exemplify the variety of possible study approaches. The Baltic-German autobiographies offer a different, sometimes opposite view of what is found in their Estonian counterparts. They supplement and vary the general picture, revealing certain aspects which were beyond the Estonians' experience. Also, they imply that the local cultural field may have been much more intervowen than some people can think of or wish to admit.

Reet Bender (b. 1974), PhD, University of Tartu, College of Foreign Languages and Cultures, Lecturer in German Philology, reet.bender@ut.ee 